\title{
DEMYSTIFYING FOUNDATION PHASE TEACHING: MALE STUDENT TEACHERS' MOTIVATION TO ENROLL FOR B.ED. DEGREE IN FOUNDATION PHASE AT A RURAL UNIVERSITY
}

\author{
F. Ravhuhali* \\ Centre for Higher Education Teaching and \\ Learning, Academic Development Unit \\ e-mail: fhatuwani.ravhuhali@univen.ac.za
}

\section{P. N. Lavhelani* \\ Centre for Higher Education Teaching and Learning, Academic Development Unit e-mail: phellecy.lavhelani@univen.ca.za}

\section{S. Mulovhedzi*}

School of Education

Department of Early Childhood Education e-mail: shonisani.mulovhedzi@univen.ac.za

\section{T. S. Mashau*}

School of Education

Department of Educational Management

e-mail: takalani.mashau@univen.ac.za

\section{N. P. Mudzielwana*}

School of Education

Department of Early Childhood Education

e-mail: ndileleni.mudzielwana@univen.ac.za

*University of Venda

Thohoyandou, South Africa

\section{ABSTRACT}

Female teachers have historically been associated with teaching profession at the Foundation Phase (FP). It is a societal belief that female teachers provide motherly love and care and are naturally soft towards infants compared to their male counterparts. This article explores a new trend that is developing at a rural university where male student teachers are increasingly enrolling for a Bachelor of Education programme where they specialise in the foundation phase (FP) teaching. The article gathered male student teachers' views for choosing teaching in the foundation phase as a career at a rural university in Limpopo Province. This qualitative case study adopted a purposive sampling procedure to sample sixteen (16) male first year B.Ed. Foundation Phase student teachers to complete open-ended questions. Content analysed data reveal that even though male student teachers were intrinsically and altruistically motivated and positive about their FP career choice and hope to demystify FP teaching, a few of them admitted that FP was a default career choice. A longitudinal cohort study is recommended in order to decipher the motivations, experiences and career paths of male FP teachers.

Keywords: career choice, Foundation Phase Teaching, pre-service male student teachers, teacher education, Foundation Phase, action plans

\section{INTRODUCTION}

There is a dire need for both male and female teachers at the Foundation Phase grades in most 
South African schools. Goal 14 in the Department of Basic Education's (DBE) Action plans stresses the need to "attract a new group of young, motivated and appropriately trained teachers to the teaching profession every year" (DBE 2015, 32). These are supposedly, young teachers of different gender orientations who amongst others, are to teach at the Foundation Phase. Significantly, the teaching profession, especially at the foundation phase in South Africa, is historically dominated by female teachers. Several studies attribute this to the maternalistic orientation of female teachers. Conversely, male teachers are perceived as "scare-crows" to infants due to their masculinity and often hard thick voices they project in class. This myth has been normalised. Notwithstanding these negative perceptions, there are few young black male students who are passionate and motivated to teach in the FP. The Foundation Phase starts from Grade R to Grade 3 with learners who are usually five and nine years old (DBE 2014). Regarded as a foundational cornerstone to quality learning, FP enables children to acquire basic literacy and numeracy knowledge that is necessary for children to make informed decisions about their future and influence change in their homes and communities. FP educators normally teach all the subjects that are within the Foundation Phase curriculum (Morake 2014). An important part of being an FP teacher includes promoting "the child's social, emotional, intellectual and physical development" (Morake 2014, 44). This article explores a new trend at a rural university where male student teachers are increasingly enrolling for a Bachelor of Education programme where they specialise in the foundation phase.

\section{REVIEW OF LITERATURE}

There are several scopes embedded within motivation to do something (Christophersen et al. 2015; Koludrović and Reić Ercegovac 2014; Özder and Motorcan, 2013; Ersozlu, 2013; Eren and Tekinarslan, 2013; Eren, 2012; Roness, 2011; Klassen et al., 2011; Biggs and Tang, 2011; Lai 2011). Ryan and Deci (2000) describe motivation as something that an individual regards as worthwhile and is also capable of influencing decision making. Accordingly, motivation is about acting which is accompanied by "being moved, energised or activated to do something" (Ryan and Deci 2000, 54). Lai (2011) argues that motivation is the reason that triggers or inspires behaviour that exhibits the will and the yearning to do something or to embark on something. "It involves a constellation of closely related beliefs, perceptions, values, interest and actions" (Lai, 2011, 2).

Jungert, Alm and Thornberg (2014) observe that when it comes to motives to select teaching as a professional career, motivations differ from one student to another. Tateo (2012) highlights that when a person choose to teach or do an initial teacher education programme, he or she might be driven by the inner desire and key features such social and cultural conditions 
within which the education system embedded. Christophersen, Elstad, Solhaug and Turmo (2015) identify five dimensions of motivation amongst student teachers, and these are extrinsic, intrinsic, achievement goal, altruistic and disillusional. Extrinsic motivation relates to contributory motives or desires that are often driven by materialistic rewards such as benefits that are attached teaching, for an example, salary, vacations or other external rewards (Lai, 2011; Eccles and Wigfield, 2002; Ryan and Deci 2000).

In the South African context, Van Broekhuizen (2015) argues that extrinsic motivation are pull factors. These extrinsic factors include amongst others, the full-costs Funza Lushaka bursaries (FLB) and the immediate absorption of the recipients of Funza Lushaka Bursary into schools upon the completion or attainment of their qualifications. This serves as a motivation for individuals to become teachers. Eren (2012) observes that some students are largely influenced by their high school results and not necessarily their inner drive to become teachers. Moreover, Armstrong (2015) argues that within the extrinsic dimension, there are a lot of motivating factors that influence an individual to choose to become a teacher such as what such an individual would earn, the number of hours to be worked, flexibility and job stability.

Unlike extrinsic factors, intrinsic motivation is based on personal enjoyment, interest, or pleasure of teaching and all the activities related to the job itself driven by inherent satisfaction or the joy of teaching (Roness 2011; Lai 2011; Ryan and Deci 2000). Guarino, Santibañez and Daley (2006) found that female prospective teachers show traits of intrinsic motivation as they often equate teaching at primary or FP more like playing a motherhood role to young kids.

About achievement goal motivation, Pintrich (2000) indicates that it is about looking at one's performance of the task and comparing that with what someone is doing. Christophersen, Elstad, Solhaug and Turmo (2015) note that achievement goal motivation has to do with the need of an individual to earn respect based on particular skills that he/she exhibits which in turn ensure that he or she is valued in a society. The same can be said about altruistic motivation which is about viewing something as worthwhile. Christophersen et al. (2015) argue that some individuals regard teaching as a socially valuable and essential profession. According to Christophersen et al. (2015), such individual would decide to choose teaching mainly because they want to play an important role in the lives of young children. On the other hand, disillusion motivation is about the feeling that can arise during teacher education training or simply when student teachers are engaged in teaching practices and are able to experience first-hand the realities of school environments, and they therefore, develop an intention to leave the teaching profession later on (Christophersen et al. 2015).

Wolhuter, Van der Walt, Potgieter, Meyer and Mamiala (2012) indicate that apart from motivations, inspiring circumstances and or settings can motivate and drive student teachers to 
enter into initial teacher education programmes, and also have potential to determine how they persist with their studies. On the other hand, Özmen (2012) points out that students' beliefs that are often traced back to early experiences at schools about the teaching profession may also have a profound impact on their decision to become teachers. Alluding to inspirational factors, Wolhuter et al. $(2012,188)$ indicate that in choosing to become teachers, students are sometimes inspired by various factors such as their own families, "friends and fellow students/peer group, their religion and faith, teaching practice in schools, the theoretical training and mentoring provided by their educators, and other contexts such as the media, culture, literature, hobbies, sport and part-time work". On the other hand, Eren (2012) argues that students' motivation to become teachers and student placement in teacher education programme is not based on what the student think is capable of or abilities, but the final year's or school leaving results. This is also intensified by lack of proper guidance that is supposed to be provided to the students while still in higher schools. Such students often find themselves choosing less undesirable professions some of which include teaching. This is supported by Armstrong (2015) who indicated that learners are encouraged to enter teacher education programmes due to low Grade 12 results especially in English, Mathematics and Science subjects. Moreover, the Centre for Development and Enterprises report (2015) highlights that the B.Ed. programmes the in most universities, has lower entrance requirements than other undergraduate degree programmes. This would seem to suggest that weaker students are attracted to the B.Ed. programme (Centre for Development and Enterprise (CDE) 2015) Technical Report.

\section{PERCEIVED GENDER STEREOTYPICAL VIEWS ABOUT FOUNDATION PHASE}

\section{TEACHING}

The Foundation Phase (FP) is dominated by a large proportion of women while men continue to shun positions to teach young kids (Petersen 2014; Mashiya 2014). Several scholars have documented the existence of gender related choices with regards to choosing to become a Foundation Phase teacher as well as the stigmatisation that goes with teaching in FP classes (Mashiya 2014; Jungert et al. 2014; Drury 2008; Mukuna and Mutsotso 2011; Petersen 2014; Sumsion 2005; Lagabrielle et al. 2011). Interestingly, being a teacher in primary school is perceived as a low status or simply "a woman's job" (Akyeampong et al. 2011, 30). Furthermore, it is associated with pitiable or unfavourable pay and opportunities for one to be promoted (Clyde 1994) and some say it is "boring, hassle causing, stressful or requires too much patience" and is therefore not a profession for men (Drury 2008, 314). As Koch and Farquhar (2015) observe, the idea of men working in lower grades is often met with people funnily and negatively joking about it as it goes against social stereotype. 
Ching-Sheue and Kun-Chung (2010)'s study found that in Taiwan male teachers become teachers as they see that as an opportunity to start a preschool business while others simply decide to be teachers because they believe the course content is easier to do. In Kenya, Mukuna and Mutsotso (2011) found that the community was often skeptical about men who tend to choose to work with or teach young children as opposed to looking for better paying professions or jobs. Moreover, Akyeampong, Pryor, Westbrook and Lussier (2011) found in Tanzania teaching at primary school or lower grades is regarded as a low status job which should only be done by females or women. Such accordance of primary school teaching to low status job has meant that male students are deterred from doing early childhood or Foundation Phase programmes. Cooney and Bittner (2001) note that some of the male teachers working with or teaching young kids even feel uncomfortable to discuss any classroom issue with their female colleagues for fear of being misunderstood.

This is contrary to what is happening in Turkey as Petersen (2014) would observe referring to findings of Akman, Taskin, Ozden, Okyay and Cortu (2014), where parents are less concerned about who is teaching their young kids in school. This may have implications such as the likelihood of an increase in the number of male student teachers who may decide to become FP teachers in the country. Sobiraj, Korek, Weseler and Mohr (2011) and Sak, Sahin and Sahin (2012) believe that just like in Turkey, the number of male teachers in Germany and the United States is likey to rise due to the changing perceptions of primary teaching professional status.

In South Africa, attitudes towards male FP student teachers indicate different sentiments being harbored about male teachers teaching in the FP. The National Teacher Education Audit Synthesis Report highlighted the feminization of the teaching profession at the primary level where the majority of teachers are females (Hofmeyr and Hall 1995). Petersen and Petker (2011) argue that in South Africa teaching in early or lower grades is associated with being a nannies and caregivers who are most likely to be female due to their maternal instincts. Moreover, culturally men are seen to be powerful to be teachers teaching young children in the Foundation Phase and as a result they are perceived to be powerful and most likely to scare young children. Bhana and Moosa (2016)'s study found that male pre-service teachers were more comfortable teaching learners in higher grades and equate that to having a higher status profession better than teaching in the Foundation Phase.

Mashiya (2014) shows that vast number of male student teachers encountered a lot of unwelcoming environments from both the principal teachers, parents as well as some learners during their practical teaching due to the fact that FP teaching is often equated to "childcare" (Mashiya 2014, 25). This would suggest that men who decide to teach at the Foundation Phase 
do so carrying with them a stigma of being abusive to female kids or simply risk being labelled homosexuals, sexual predators and paedophiles, frightening or scaring children, and being bad caregivers of young children. Mashiya (2014) indicates how student teachers who choose Foundation Phase teaching often come across continuous skepticisms, funny criticism and degradation from fellow students who are specialising in other phases regarding FP teaching choice, communities where student teachers come from and where they do their practical teaching and or their actual teaching after graduating (Mashiya 2014). Moreover, the Foundation Phase teaching profession is given very little status in South African society (Gallant 2012). The array of studies discussed in this article show persistent stereotyping of male teachers who are sometimes perceived to be sexual predators and paedophiles who are capable of sexually molesting young children. It is on this basis that this article sought to gather male student teachers' reasons and views for pursuing a teaching career in the foundation phase by enrolling for B.Ed.TEF now as Foundation Phase in a rural university in the Limpopo Province.

\section{THE ARTICLE'S THEORETICAL UNDERPINNING}

Sandra Bem's (1981) Gender Schema Theory allows for an analysis and understanding of various stereotypes embedded within gender issues and how these emerge as cultural and societal belief systems. It is within this context that Gender Schema Theory was propounded to advance public awareness on the male-female contradictions that play out in various societal structures. The Gender Schema Theory posits that as children are born, grow and develop, their culture taught them the difference between male and female. Moreover, people learn from an early age what each particular role of either male or female entails as upheld by the culture and the society they live in. Bem (1981) argues that even though there are societal differences in terms of the explicit roles assigned to both male and female, the allocation of adult roles are based on sexual orientation. Moreover, societies expect and anticipate such gender-based allocation of roles in the socialisation of their children.

Early in their lives children had to adjust their behaviour to socially acceptable and anticipated gender norms of their culture. Most importantly, it is expected of the children to attain some kind of sex-based specific skills and sex-specific self-concepts and disposition as prescribed by their culture and society (Bem 1981). Such tendencies and behaviours manifest themselves as gender stereotypes and are intuitively entrenched in different societal and cultural norms and values and seen as acceptable standards of life. In the end, being male and female tend to have long lasting influence in the development and adoption of gender-based roles that are perceived to be rigid and acceptable in society (Petersen 2014). 


\section{RESEARCH DESIGN AND METHODOLOGY}

This article is qualitative in nature. Creswell $(2012,626)$ defines qualitative design "as an enquiry approach useful for exploring and understanding a central phenomenon". This case study was comprised of first year male student teachers drawn from a population of male student teachers enrolled in B.Ed. Foundation Phase (FP) programme in a rural university in Limpopo Province. A purposive sampling procedure was used to engage through open-ended questions only a group of sixteen (16) B.Ed. Foundation phase male students in their first year of study. Open-ended questions provided participants with opportunities to share their reasons for choosing Foundation Phase teaching in full as well as an opportunity to express themselves freely to the questions, which in turn result in a greater variety of information (Cresswell 2012; Okeke and Van Wyk 2015; Kumar 1996). Content and thematic analysis were adopted for analysis purposes.

\section{FINDINGS AND DISCUSSION}

This section explains the informants' views in the context of the article's main concern. From the open-ended questions, themes were identified as main reasons for male students' explanations and motives for choosing to become Foundation Phase teachers. The following five themes emerged: addressing gender equality; being father-figure roles; making a difference in children's lives; passion and love for children and Foundation Phase (FP) a default career choice. Verbatim quotes are presented to support participants' statements. The MS1-M16 (Male Students) codes are used for each respondent.

\section{Addressing gender equality and demystifying gender stereotype in the Foundation Phase}

Participants indicated that they became FP teachers because there are currently few male teachers at the Foundation Phase. Participants said they wanted to be among male teachers who teach early schooling grades, especially in the FP. Some of the responses were as follow: $\mathrm{MS}_{1}$ revealed that he chose Foundation Phase (FP) based on his experience or what he observed while still in primary school where they had no male teachers in the FP grades. This meant that there was no one to assist them with sporting activities as female teachers did not let them participate in sports such as soccer. $\mathrm{MS}_{2}$ and $\mathrm{MS}_{3}$ highlighted the overrepresentation of female teachers in the FP and that this prompted them to enroll for a FP degree in order to ensure that learners have some male teachers who can be father-figure role models. On the other hand, $\mathrm{MS}_{5}$ and $\mathrm{MS}_{6}$ wanted to become teachers for FP grades in order to demystify gender stereotype that 
FP teaching is only for women and want to make a difference at primary school because a lot of people think that teaching at Foundation Phase is for women. Other participants made the following observations: $\mathrm{MS}_{12}$ : To be a teacher has always been my passion but I chose to be a FP teacher because I wanted to balance gender equality. It is always taken for granted that male teachers don't teach on the FP it is not true. People need to understand that there is a need for more male teachers in the FP.

$\mathrm{MS}_{10}$ : "The reason why I choose this career is simply because I wanted to contribute on gender equality in the Foundation Phase (FP) grades. Previously, and even now it is very rare to see a male teacher in the FP or in reception year. I want to show others that not only women are meant to teach young children, but males can also contribute in helping young kids towards achieving better education, I also want to prove people's perception wrong especially women and others who think and believe that teaching in the FP is for female teachers."

$\mathrm{MS}_{9}$ : "I choose to be a Foundation Phase teacher my reason being that from my village where I'm from there are shortages of male teachers; therefore, I want to be part of the male teachers teaching the FP grades."

$\mathrm{MS}_{7}$ : "I have noticed that in our country there are shortages of male teachers in the Foundation Phase so I wanted to show my community and our country that even males can be FP teachers."

The reasons why these male students decided to enroll for Foundation Phase degree seem to echo sentiments by Petersen (2014) who indicates that FP has always been dominated by females. This is attributed to stereotypical beliefs that FP is a childcare phase and a low-status job where teachers are responsible for looking after infants (Drury 2008; Mashiya 2014; Deacon 2012). UNESCO Bangkok (2004) highlights that men often suffer from socially-constructed gender stereotypes that force them to put on a mask of being "tough" and being the "breadwinner". The stereotypical perceptions which are often learnt from early ages (Bem 1981), have meant that men are not expected to occupy any role that is perceived to be meant for female and in no way expected to care for both young children or to show compassion (UNESCO Bangkok 2004).

However, Kadane (2017) reasons that for male student teachers choosing to teach in the FP is not just about motivation and hope to work in the predominately female terrain, it also has its own benefits, especially for the young children. Accordingly, it has a positive impact on children as it contributes to healthy and conducive school culture which in turn enhances creativity as well as promoting innovation and changes the way children think (Kadane 2017). Even though Kadane (2017) admits that changing demographics is a challenge due to entrenched perception of lower grades teaching as women job, men teaching in those lower 
grades as Foundation Phase are simply opposing the norm, ignoring stigma and are doing that because they really want to teach children. Furthermore, men who take such courage are those who see FP teaching as a meaningful career where they can make a difference (Kadane 2017). The same sentiments are echoed by Murray (2009) who argues that young children, especially boys, benefit enormously from simply seeing a male teacher reading and writing with them and can also go a step further in challenging them to work even harder at school. The importance of having male teachers teaching in lower grades are that it affords children an opportunity to have someone of they think can assist them if and when they are facing various bullying problems in school (Murray 2009). Not only do young girls, particularly those living with their mothers only or single parents, benefit from having male teachers but, they are also able benefit holistically when having men as teachers in early grades.

\section{Being father-figure roles}

Participants also stated that they have chosen a career in teaching FP classes so that they can play roles of father-figures to the young learners. $\mathrm{MS}_{1}$ indicated that most children in South Africa do not have father figures at home. So he believes that he can be one of those role model father figures to all of them but especially the fatherless ones. This was echoed by $\mathrm{MS}_{9}$ who stated that the majority of young learners only know females as their teachers and in the FP grades. So he would like young male learners to be comfortable when they see male figures as their teachers in the FP. In support of this, $\mathrm{MS}_{6}$ noted:

"My reason is that I want to become a father to the fatherless and to show that men can also care about young children and to show equality in the learning process in the Foundation Phase (FP) because people say it is only females who can teach young children."

Mcweeney (2014) argues that it is very problematic there are a lot of children who lack positive father figure and a role model. This is especially a problem with children who come from singleparent families. Clearly, the absence of men tends to place boys at a disadvantage and the presence of male teachers gives them an opportunity of having a male figure to relate to in the classroom (Mcweeney 2014). Brownhill (2015), Puhani (2015) and Zirkel (2002) share the same sentiments and note that when taught by male teachers, male learners are able to have someone similar to a role model with whom they can associate in order to attain positive gender orientation. Moreover, Deese (2017) alludes to this and argues that when male children are taught by and are able to see male teachers, they may benefit a lot by observing appropriate behaviors, especially those that are related to handling anger, respect for others and obeying rules. 


\section{Passion and love for children}

For $\mathrm{MS}_{4}$ and $\mathrm{MS}_{6}$, choosing to teach in the $\mathrm{FP}$ was motivated by their ultimate love for children and the fact that children fun-loving, entertaining and easy to understand. $\mathrm{MS}_{7}$ echoed the same sentiments and indicated that he chose the Foundation Phase teaching because he really loves children and that he enjoys playing with them. He is also fascinated by their creativity and carefree personalities. Some participants stated the following:

MS 8 : "I love little children and I have always dreamt of being a teacher who will produce the best learners and be able to give a good foundation to all the young children."

$\mathrm{MS}_{11}$ : "I choose this degree because I have love for young children and I want a better education for them. Teaching young kids is what I always wanted since I was in high school. All what I want is a better future for young South Africans."

$\mathrm{MS}_{12}$ : "I love young children, they are very clever. I have three (3) little nephews at home and that has made me to change from B.EdFET (Further Education and Training) to B.Ed.TEF (Foundation Phase) degree programme as it will allow me to spend most of my time with young children because I love young children very much."

According to Murray (2009), when the vast number of male teachers teaching in lower grades are asked to share reasons why they were attracted to the profession, they often reveal that they saw it as a worthwhile career. This response mirrors the DBE's appeals to individuals to turn their love of learning into a love of teaching. This means that any individual who loves to learn has to turn that passion to teaching young kids and sharing such passion of learning with them. Secondly, the DBE urges everyone especially the young ones to pass on their love of learning and help students discover their potential. It can be argued that there is a need for every individual to look at teaching as an act of inculcating a sense of discovering oneself, abilities, potentials values capacities and skills to help the individual in the future. Teaching should be viewed as helping the child grow like a mother helping the child to walk and talk. Thirdly, there is a call for everyone to consider teaching as an ideal career choice through which one can experience the joy of seeing children learn to read, write and count; and set them on a path to success. Moreover, the DBE articulates about the need for young people to see teaching as a way of serving the children, one's own community and country. By choosing to teach, one becomes a custodian or an overseer of his community and society, and most importantly, the country. Each country looks upon the teachers to nurture and develop young children to be holistic human beings. Teachers are also in a position of sharing their knowledge in order to make the world a better place. This is about disseminating what one knows, has experienced, learnt, and one's beliefs. Teachers also have to help children understand the values that make 
South Africans strong and proud and in the process produce patriotic citizens. This is tied to understanding that by choosing teaching as a profession, one is contributing towards nation building and perhaps social cohesion. Furthermore, teaching allows the teacher to see the world through the eyes of a child and learn something in return. The DBE's argument is that teaching should be viewed as a two-way system: it is teaching and learning, and learning to teach is learning, and understanding that being a teacher is being a learner. This is driven by inner fulfilment and the quest to see children developing every day, learning new things day by day resulting in making a difference in children's lives as discussed in the next theme.

\section{Making a difference in children's lives}

Some participants indicated that they chose FP teaching career as they are driven by the need to make a difference in children's lives. For example, $\mathrm{MS}_{4}$ confirmed that he chose FP teaching career in order to make a difference in young children' lives as he loves children very much. Similarly, $\mathrm{MS}_{6}$ had this to say:

"I choose Foundation Phase teaching because I really love children and as a male teacher I want to make a difference in their lives by teaching them from primary school because a lot of people think that teaching at foundation phase is for women only."

The DBE (DBE n.d.) makes a passionate call for everyone to consider teaching as a step that might culminate to making the same difference to children's lives as much as their own teachers who tremendously in making a lot of difference in their lives. The expressions by participants about deciding to teach in the Foundation Phase would support Halvorsen (2014) who states that student teachers often believe that they are capable of making a difference in learners' lives. This shows that their caring identity is underpinned by the notion that "we are what we are because there was a teacher". These men are bold enough to disregard any gender perception stereotype and chose to teach early grades or Foundation Phase children while at the same time they are challenging perceived gender role that are culturally assigned in their societies (Brody 2015). The participants believe that they were shaped in some ways by their teachers and to them teaching is about making someone to be somebody. The DBE's other objective is to ensure that those who choose to teach are able to "ignite the spark of curiosity in children". The understanding here is that teaching is accompanied by the notion of "wanting to share the light of wisdom to inquire, reason, explore, discover and solve life's challenges". UNESCO Bangkok (2004) argues that if and when men participate in promotion of gender equality, there are fundamental gains that are accrued by the entire society especially in education where persistent disparity still exists. Moreover, the DBE says they is a need to "mould and shape ordinary 
children into extraordinary citizens" as one of the reason why people should consider the teaching profession (DBE n.d., 1). Accordingly, becoming a teacher means being tasked with the responsibilities to make a difference in children's lives. As much as someone made teachers who they are today, by teaching young children, they are in a way making children to be someone else. This would also mean that a person who chooses to teach should be motivated by the quest to help children to be extraordinary human beings capable of making new discoveries and being innovators.

\section{Foundation Phase as default career choice}

Although for almost all the participants Foundation Phase teaching appeared to be a career of choice, others noted that it was a default career choice. Those participants indicated that it was not their dream to teach in the Foundation Phase but only decided to do it when they could not get admission into their first choice degree. Even though FP teaching was their default career choice, they are slowly falling in love with it and are looking forward to working with young kids. $\mathrm{MS}_{13}$ and $\mathrm{MS}_{15}$ indicated that even though they are starting to enjoy the programme's activities, Foundation Phase was a default career choice for them. $\mathrm{MS}_{15}$, in particular, had applied for admission into Bachelor of Education Further Education and Training (B.EdFET) as his first choice and Bachelor of Education Foundation Phase (B.EdTEF) was his second choice. Despite FP teaching being a default career for them, they are now willing and interested to learn more about the course itself. They are little bit anxious about working with young kids and think it is going to be a great challenge teaching them. $\mathrm{MS}_{13}$ indicated that he thinks getting admitted to do FP degree was a chance worth taking as he will be contributing to having more male teachers readily available to teach in the Foundation Phase classes as there are very few men teaching in the phase. The following are responses of two participants whose initial intentions were not enroll for FP degree:

$\mathrm{MS}_{3}$ : "NO! Foundation Phase was not my choice, mine was Social Work but I ended up taking Foundation Phase teaching because of the advice that I got from my aunt and uncle who are both teachers. Now I'm starting to really love the teaching profession."

$\mathrm{MS}_{10}$ : "I must say I didn't want to teach at Foundation Phase but thanks to my lectures I'm falling in love with FP and now I want to do my things with passion and love, maybe it is a calling. Through one of my FP lecturers I see many doors unlocked for me and now I love and value teaching in the Foundation Phase."

The responses from participants $\mathrm{MS}_{13}, \mathrm{MS}_{15}, \mathrm{MS}_{3}$ and $\mathrm{MS}_{10}$ suggest that $\mathrm{FP}$ was a fall back career choice since it was never their intention to choose such a career path. One of the reasons why they may not have wanted to teach at Foundation Phase could either be that society still 
views males teaching early year classes suspiciously. This discourages those who might be thinking of entering the profession (Mistry and Sood 2015). Mashiya (2014) indicates that in various communities, having a male Foundation Phase teacher is rare. More shocking is when teachers who are supposed to offer preservice or student teachers mentorship and inductions tend to discourage and make fun of some of them. It is for this reason that Mistry and Sood (2015) advocate that FP male student teachers be provided with mentoring in order to help them overcome the perceived contextual barriers of male stereotypes.

\section{IMPLICATIONS ON TEACHER EDUCATION POLICIES AND CONCLUSION}

The findings of this article do not replicate the findings of the study conducted by Deacon (2015) which reveals that student teachers were motivated to become teachers in order to help improve the quality of education in South Africa and share their acquired discipline knowledge. Even though the FP teaching career was not a first choice for some of the male student teachers, this article reveals their optimism and determination to teach learners in the phase. Male student teachers hope to demystify FP teaching and contribute immensely to the holistic development of young children. This resonates well with altruistic motivation which entails viewing teaching as a socially worthwhile and important job as it offers opportunities to work and be part of young peoples' growth and development. It is worth noting and pointing out that when the White Paper on Education and Training in a Democratic South Africa was ratified in 1995 (Republic of South Africa Department of Education 1995), it was built on the premise of building a system of education and training founded on equity and non-discrimination, and with which all the people can identify, owned and cared for, because it serves their needs and interests. Furthermore, The White Paper 3: A Programme for Transformation of Higher Education system in 1997 highlighted the inequitable distribution of access and opportunity for students and staff along lines of race, gender, class and geography as well as the gross discrepancies in the participation rates of students from different population groups as one of the biggest challenges faced in the higher education system (Republic of South Africa Department of Education 1997). These policies provide the foundation for non-discrimination in South Africa as enshrined in the Employment Equity Act (1998) 55 of 1998 which seeks to ensure that a diverse workforce broadly representing all the people is achieved. Unfortunately, such has not been realised as male student teachers are still being marginalised in the FP on the basis of their gender something that has potential of having indirect and unintended consequences in the holistic development of children. Even though some of the male student teachers admitted that FP was a default career choice, they were intrinsically and altruistically motivated and are positive about their FP career choice and hope to demystify FP teaching. Furthermore, the findings 
reveal that the male student teachers exhibited knowledge of their societal and cultural expectations in relation to their male gender status and are cautiously aware of what is expected from them in relation to their role as men from societal point of view. Interestingly, the prospective male FP teachers are determined to demystify and defy the entrenched societal and cultural norms and values which dictate that certain roles are meant for a specific gender.

Drawing from the findings of this article, there is still a need for male student teachers to continue identify, own and care for what they identity themselves with. Given what is articulated in both Education policies, choosing the Foundation Phase teaching should not only be to serve student teachers' needs and interests such as ensuring gender parity prevails in what is perceived to be female dominated phase, or simply the love of working with young kids. The choice to become Foundation Phase male teachers must continuously and cautiously be based on the quest to ensure that the national needs are fully addressed as envisaged in the National Development plans (NDP), DBE's Action plans and Strategic Plans. More needs to be done such as the recommendations by UNESCO Bangkok (2004) which suggested that there is a need for whole some changes in society if gender equality is to be achieved. That should involve various and robust systematic policy changes and how gender roles are to be fully comprehended to contribute meaningfully throughout the various levels of our society such as home, workplace, schools, public service and many other societal spaces at large. Such engagements can include colloquia to engage various stakeholders in a frank yet robust discourse on the role and benefits of male teachers teaching young children in the Foundation Phase. Given that the article highlights the motivation and hope for male student teachers to teach in and demystify FP, a longitudinal cohort study needs to be conducted to understand their experiences during their teaching practicum and their career paths.

\section{REFERENCES}

Akman, B., N. Taskin, Z. O. Ozden, O. Kyay and F. Cortu. 2014. Parents' views on the appointment of male teachers in Turkish preschool. Education as Change 18(1): 21-32.

Akyeampong, K., J. Pryor, J. Westbrook and K. Lussier. 2011. Teacher preparation and continuing professional development in Africa: Learning to teach early reading and mathematics. Centre for International Education, University of Sussex. www.sussex.ac.uuk/cie/documents/tpa-synthesisreport-july(2011).pdf (Accessed 26 May 2015).

Armstrong, P. 2015. Teachers in the South African education system: An economic perspective. Econex, Research Note 39 October 2015. http://econex.co.za/wp-content/uploads/2015/10/ECONEX_ researchnote_39.pdf (Accessed 1 December 2015).

Bem, S. L. 1981. Gender schema theory: A cognitive account of sex typing. Psychological Review 88(4): 354-364.

Biggs, J. and C. Tang. 2011. Teaching for quality learning at university: What the students' does. $4^{\text {th }}$ Edition. New York: Society for Research into Higher Education \& Open University Press.

Bhana, D. and S. Moosa. 2016. Failing to attract males in foundation phase teaching: An issue of masculinities. Gender and Education 28(1): 1-19. DOI: 10.1080/09540253.2015.1105934. 
Brody, D. L. 2015. The construction of masculine identity among men who work with young children, an international perspective. European Early Childhood Education Research Journal 23(3): 351361. DOI: 10.1080/1350293X.2015.1043809.

Brownhill, S. 2015. The "brave" man in the early years (0-8): Defining the "role model". European Early Childhood Education Research Journal 23(3): 370-379. DOI: 10.1080/ 1350293X.2015.1043811.

Centre for Development and Enterprise. 2015. Technical Report: Teacher supply and demand 20132025. Parktown, Johannesburg, Centre for Development and Enterprise.

Ching-Sheue, F. and L. Kun-Chung. 2010. Learning experiences of male pre-service teachers in Taiwan. New Horizons in Education 58(2): 34-42.

Christophersen, K-A., E. Elstad, T. Solhaug and A. Turmo. 2015. Gender variations in Norwegian preservice teachers' motivational orientations. Problems of Education in the $21^{\text {st }}$ Century 63(2015): $17-28$.

Clyde, M. 1994. Men in early childhood: What do women think about it? Early Childhood Education Journal 29(2): 77-82.

Cooney, M. H. and M. T. Bittner. 2001. Men in early childhood education: Their emergent issues. Early Childhood Education Journal 29(2): 7-82.

Cresswell, J. W. 2012. Educational research: Planning, conducting and evaluating quantitative and qualitative research. $4^{\text {th }}$ Edition. Boston: Pearson.

Deacon, R. 2012. The initial teacher education research project: The initial professional development of teachers: A literature review. Johannesburg: JET Education Services.

Deacon, R. 2015. The initial teacher education research project: Newly qualified teachers in South Africa. Report on the 2014 telephonic follow-up survey of the 2013 class of final year initial teacher education students. Johannesburg: JET Education Services.

Deese, H. 2017. Male teacher shortage affects boys who need role models. USA TODAY Back to School magazine 22 July 2017. https://www.usatoday.com/story/news/2017/07/22/male-teachershortage-affects-boys-who-need-role-models/103585138/ (Accessed 16 February 2018).

DBE see Department of Basic Education.

Department of Basic Education. 2015. Action Plan to 2019: Towards the realisation of schooling 2030. Taking forward South Africa's National Development Plan 2030.

Department of Basic Education. 2014. Annual Report 2013/14, Vote No.15. Pretoria: Department of Basic Education. https://www.gov.za/sites/default/files/gcis_document/201410/dbeannualreport 2013-14a.pdf (Accessed 16 February 2016).

Department of Basic Education. n.d. "Make a difference ... become a teacher". http://www.education. gov.za/Educators/InitialTeacherEducation/tabid/416/Default.aspx (Accessed 23 July 2015).

Drury, S. 2008. Gender balance/gender bias: The teaching profession and the impact of feminisation. Gender and Education 20(4): 309-323.

Eccles, J. S. and A. Wigfield. 2002. Motivational beliefs, values, and goals. Annual Reviews of Psychology 2002(53): 109-132.

Employment Equity Act. 1998. Act 55 of 1998, issued in terms of Section 25(1), Vol. 400 and No. 19370. Cape Town. Office of President of the Republic of South Africa.

Eren, A. 2012. "Prospective teachers' interest in teaching, professional plans about teaching and career choice satisfaction: A relevant framework?" Australian Journal of Education 56(3): 303-318. https://doi.org/10.1177/000494411205600308

Eren, A. and E. Tekinarslan. 2013. Prospective teachers' metaphors: Teacher, teaching, learning, instructional material and evaluation concepts. International Journal of Social Sciences and Education 3(2): 435-445.

Ersozlu, Z. N. 2013. Profiling pre-service teachers' reasons of teaching in Turkey. International Journal of Advanced Research 1(7): 485-494. 
Gallant, R. J. 2012. Foundation phase teachers' continuous professional development. A dissertation submitted in fulfilment of the requirements for the degree Magister Education in the Faculty of Education at the Nelson Mandela Metropolitan University. http://www.Foundation+Phase + Teachers\%2527+Continuous+Professional+Development_RJGALLANT\%20(1).pdf (Accessed 15 August 2015).

Guarino, C., L. Santibañez and G. Daley. 2006. Teacher recruitment and retention: A review of the recent empirical literature. Review of Educational Research 76(2): 173-208.

Halvorsen, K. V. 2014. Building teacher identity in a new partnership project - Multiple perspectives. Journal of Studies in Education 4(1): 11-24.

Hofmeyr, J. and G. Hall. 1995. The National Teacher Education Audit: Synthesis Report. Johannesburg: Edupol, National Business Initiative.

Jungert, T., F. Alm and R. Thornberg. 2014. Motives for becoming a teacher and their relations to academic engagement and dropout among student teachers. Journal of Education for Teaching 40(2): $173-185$.

Kadane, L. 2017. The importance of male teachers. Today's Parents. https://www.todaysparent.com /kids/the-importance-of-male-teachers/ (Accessed 21 December 2017).

Klassen, R. M., S. Al-Dhafri, W. Hannok and S. M. Betts. 2011. Investigating pre-service teacher motivation across cultures using the Teachers' Ten Statements Test. Teaching and Teacher Education 27(2011): 579-588.

Koch, B. and S. Farquhar. 2015. Breaking through the glass doors. Men working in early childhood education and care with particular reference to research and experience in Austria and New Zealand. European Early Childhood Education Research Journal 23(3): 380-391.

Koludrović, M., and I. Reić Ercegovac. 2014. Academic motivation in the context of self-determination theory in initial teacher education. Croatian Journal of Education 7(Sp. Ed. No.1/2015): 25-36.

Kumar, R. 1996. Research methodology: A step-by-step guide for beginners. London: SAGE Publications

Lai, E. R. 2011. Motivation: A literature review research report. http://images.pearsonassessments. com/images/tmrs/Motivation_Review_final.pdf(Accessed 15 August 2015).

Lagabrielle, C., A. M. Vonthron, D. Pouchard and J. Magne. 2011. "L'intention desemaintenir dans une carrière atypique: Quels déterminants individuels et contextuels?" Psychologie du Travail et des Organisations 17: 193-209.

Mashiya, N. 2014. Becoming a (male) foundation phase teacher: A need in South African schools? South African Journal of Childhood Education 4(3): 24-36.

Mcweeney, D. M. 2014. Male teachers needed in primary grades. The Hartford Courant. http://www.courant.com/opinion/op-ed/hc-op-fresh-talk-mcweeney-need-male-elementary-tea20140722-story.html (Accessed 15 December 2017).

Mistry, M. and K. Sood. 2015. Why are there still so few men within Early Years in primary schools? Views from male trainee teachers and male leaders? Education 3-13 43(2): 115-127. DOI: 10.1080/03004279.2012.759607.

Morake, M. N. 2014. The implementation of professional development in the Foundation Phase in the North West Province with reference to Curriculum and Assessment Policy Statement. Unpublished study submitted in accordance with the requirements for the degree of Doctor of Education in the subject Education Management at the University of South Africa. http://uir.unisa.ac.za/bitstream/handle/10500/13756/thesis_morake_mn.pdf;jsessionid=8255CE4 B0F0E70CBCDA3790A7C3F8ECD?sequence=1 (Accessed 26 June 2018).

Mukuna, T. E. and S. N. Mutsotso. 2011. Gender inequalities in early childhood development education teaching profession in Kenya. Educational Research 2(13): 1876-1885.

Murray, J. 2009. One in four primaries have no male teachers at all. So how did one school end up with 15? The Guardian Tuesday 31 March 2009. https://www.theguardian.com/education/2009/mar/ 31/primary-school-teachers (Accessed 21 December 2017). 
Okeke, C. and M. van Wyk. (Ed.). 2015. Educational research: An African approach. Cape Town: Oxford University Press.

Özder H. and A. Motorcan. 2013. An analysis of teacher candidates' academic motivation levels with respect to several variables. British Journal of Arts and Social Sciences 15(1): 42-53.

Özmen, K. S. 2012. Exploring student teachers' beliefs about language learning and teaching: A longitudinal study. Current Issues in Education 15(1): 115. http://cie.asu.edu/ojs/ index.php/cieatasu/article/view/819 (Accessed 23 July 2015).

Petersen, N. and G. Petker. 2011. Foundation phase teaching as a career choice: Building the nation where it is needed. Education as Change 15(Supplement Number 1): 49-61.

Petersen, N. 2014. The "good", the "bad" and the "ugly"? Views on male teachers in foundation phase education. South African Journal of Education 34(1): 1-13.

Pintrich, P. R. 2000.An achievement goal theory perspective on issues in motivation terminology, theory, and research. Contemporary Educational Psychology 25(1): 92-104.

Puhani, P. A. 2015. Do boys benefit from male teachers in elementary school? Evidence from Administrative Panel Data. University of St. Gallen; IZA, Bonn. http://legacy.iza.org/en/ papers/264 19042016.pdf (Accessed 15 December 2017).

Republic of South Africa Department of Education. 1997. Education White Paper 3: A Programme for the Transformation of Higher Education. Pretoria: DoE, NOTICE 1196 OF 1997. Government Gazette No. 1820715. Augustus 1997.

Republic of South Africa Department of Education. 1995. White Paper on Education and Training in a Democratic South Africa, First Steps to Develop a New System, Pretoria: No. 16312. Government Gazette, Notice no. 196 of 1995.

Roness, D. 2011. Still motivated? The motivation for teaching during the second year in the profession. Teaching and Teacher Education 27(2011): 628-638.

Ryan, R. M. and E. L. Deci. 2000. Self-determination theory and the facilitation of intrinsic motivation, social development, and well-being. American Psychologist 55(1): 68-78.

Sak, R., I. K. Sahin and B. K. Sahin. 2012. Views of female pre-service teachers about male teaching colleagues. Social and Behaviour Sciences 47: 586-593.

Sobiraj, S., S. Korek, D. Weseler and G. Mohr. 2011. When male norms don't fit: Do traditional attitudes of female colleagues challenge men in non-traditional occupations? Sex Roles 65: 798-812.

Tateo, L. 2012. What do you mean by "teacher"? Psychological research on teacher professional identity. Psicologia \& Sociedade 24(2): 344-353.

UNESCO Bangkok. 2004. Role of men and boys in promoting gender equality - Advocacy brief AsiaPacific Programme of Education for All (APPEAL) Bangkok: UNESCO Asia and Pacific Regional Bureau for Education. http://unesdoc.unesco.org/images/0013/001377/137780e.pdf (Accessed 27 January 2017).

Van Broekhuizen, H. 2015. Teacher supply in South Africa: A focus on initial teacher education graduate production. Working Paper of the Department of Economics and the Bureau for Economic Research at the University of Stellenbosch, WP07/15. http://www.google.co.za/url? $\mathrm{sa}=\mathrm{t} \& \mathrm{rct}=\mathrm{j} \& \mathrm{q}=\& \mathrm{esrc}=\mathrm{s} \&$ source $=$ web\& $\mathrm{cd}=3 \& \mathrm{ved}=0 \mathrm{CDUQFjACahUKEwjK5Zrkkf}$ IAhVEtxQ KHaP5DoI\&url=http\%3A\%2F\%2Fwww.ekon.sun.ac.za\%2Fwpapers\%2F2015\%2Fwp072015\% 2Fwp-07-2015.pdf\&usg=AFQjCNG7hX76JtIa0I7tqObNQDrviMDSmA $>\quad$ (Accessed 7 November 2015).

Wolhuter, C., H. van der Walt, F. Potgieter, L. Meyer and T. Mamiala. 2012. What inspires South African student teachers for their future profession? South African Journal of Education 32(2): $178-190$

Zirkel, S. 2002. "Is there a place for me? Role models and academic identity among white students and students of color." Teachers College Record 104(2): 357-376. 